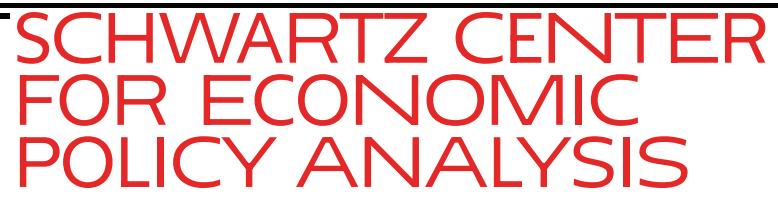

Veiled Repression: Mainstream Economics, Capital Theory, and the Distributions of Income and Wealth

\title{
Lance Taylor
}

\section{Schwartz Center for Economic Policy Analysis (SCEPA)}

Department of Economics

The New School for Social Research

6 East 16th Street, New York, NY 10003

economicpolicyresearch.org

Suggested Citation: Taylor, L. (2015) "Veiled Repression:

Mainstream Economics, Capital Theory, and the

Distributions of Income and Wealth." Schwartz Center for Economic Policy Analysis and Department of Economics, The New School for Social Research, Working Paper Series 2015-8.

Supported by the Institute for New Economic Thinking. Comments by Thomas Ferguson, Duncan Foley, and Armon Rezai are gratefully acknowledged. 
Revised 25 May 2016

\section{Lance Taylor}

\section{Veiled Repression: Mainstream Economics, Capital Theory, and the Distributions of Income and Wealth}

Abstract: The Cambridge UK vs USA capital theory debates of the 1960s showed that the workhorse mainstream growth model relies on unsustainable assumptions. Its standard interpretation is not consistent with the last four decades of data. Part of an estimated increase in the ratio of personal wealth to income in recent years is due to higher asset prices. The other side of the accounts reveals that financialization and growing business debt partially offset the greater net worth of households. Attempts to interpret growth in wealth principally as a consequence of capitalization of rents are misleading but capitalization of a rising profit share helps explain an upward trend in Tobin's q. Growth models based on Cambridge UK ideas can help correct these misinterpretations.

JEL codes: D3, E1

Key words: Income distribution, wealth distribution, Cambridge controversies

Arnhold Professor emeritus, New School for Social Research. Supported by the Institute for New Economic Thinking. Comments by Thomas Ferguson, Duncan Foley, Armon Rezai, and two referees are gratefully acknowledged. 
In the USA, thanks to the Occupy movement, Thomas Piketty's Capital in the Twenty-First Century (2014), and Senator Bernie Sanders, questions about the distributions of income and especially wealth are now fully in the public eye. But there are aspects that need to be explored. We begin with a summary, and then go on to the details.

\section{Key observations}

An economic growth model must be the backbone of any attempt to analyze distributional changes over time. Long ago, the "Cambridge controversies" over capital theory showed that the workhorse mainstream model adopted by Piketty has grave deficiencies. If the total value of capital is set by cost including profits, then it has no clear relationship with the profit rate. Consequently, the standard model's postulate of diminishing returns to capital is untenable. In use, moreover, the model's narrative of steady decreases in the output/capital ratio and profit rate does not fit the data (see Figure 1 below).

A second important point is that growth models usually presume that households own (or at least control) the entire capital stock. In fact they basically own residential capital plus a complicated set of claims against business (which owns productive capital), the government (infrastructure) and the rest of the world. As discussed in more detail below, net worth of the private (household and business) sector is set by the supply of primary assets, to the right of the equals sign,

$$
\begin{aligned}
& \text { Household wealth + business wealth } \\
& \text { = Capital + Government debt + Net foreign assets . }
\end{aligned}
$$


Shifts in such a system need to be analyzed in terms of both the stocks involved and their changes (or flows) over time. In flow terms for each income category it must be true that

Change in wealth $=$ Net saving + Capital gains .

Within the private sector, national income flow accounting assures that

Total profits $\approx$ Financial transfers to households + Business saving

in which financial transfers are net interest and dividend flows.

If households are to receive all profits from capital, the question is how do they get their hands on flows of business saving? The empirical answer is that capital gains on equity and housing in the USA typically exceed business saving net of depreciation. In terms of stocks the outcome has been that James Tobin's (1969) "valuation ratio" or $q-a$ firm's equity valuation divided by the replacement value of its capital stock (or perhaps capital minus net financial liabilities) rose steadily after the early 1980s. Either way, control of capital more than passes to households via capital gains for them and capital losses for business. (This pattern is not universal; it is not observed in Germany, where there are low equity valuations relative to capital, a value of $q$ less than one, and positive business net worth.)

Third, in the recent debate, a key question is how to estimate the value of capital. Ignoring Cambridge complications, the widely applied "perpetual inventory" method calculates the costs of producing new capital goods and takes into account how rapidly they depreciate in use.

Another approach, adopted by Piketty, is to estimate the value of capital on the basis of stock market valuations. "Intangible capital" (whatever that is) then explains a 
substantial increase over perpetual inventory estimates. With a high enough value of capital, household wealth can be large and business wealth near zero. "Capital is back" largely because equity-based estimation makes it happen.

Fourth, similar observations apply to the valuation of residential capital. Here the options are perpetual inventory vs. capitalization of "rents," whether legally legitimate or the results of monopoly power, political clout, or corruption. New billionaires' towers along Manhattan's $57^{\text {th }}$ street notwithstanding, capitalization of real estate rental flows as estimated in the national accounts yields estimates of residential capital in the range of one year's GDP, roughly the same as perpetual inventory calculations.

With regard to capital, Figure 1 shows that the corporate profit share of output has risen by around five percentage points since the 1970. As labor's bargaining power has been eroded (details below) the growth of the output/labor ratio (or productivity) has outrun the growth of real wages. Capitalizing that extra business income suggests an increase in the value of enterprise which is also in vicinity of one year's GDP, or roughly half the value of outstanding equity. Piketty's stock market based estimate of the value of capital and the rise in Tobin's $q$ are consistent with capitalization of rising profits accompanied by lagging wages.

Finally, applying Cambridge-style growth models suggests four conclusions.

First, increases over recent decades of the profit share and output/capital ratio can be rationalized on the basis of a structural distributive shift toward profits in a demand-driven medium-run model in which there is a cyclically weakening profit share as output goes up, and the level of output rises with higher profits. 
Second, in the "long run" at the model's steady state, Piketty's inequality $r>g$ (profit rate exceeds the growth rate) follows simply from the accounting. It is not some newly discovered law of capitalism.

Third, extending the analysis to the long run shows that there is an upper bound to the share of wealth held by "capitalists" because they do not control saving from most of wage income.

Fourth, households in the top one percent in the USA largely rely on capital income and also have a high and historically rising level of earned incomes per household. As noted above, their capital gains tend to exceed business retain earnings net of depreciation. Rich households have relatiely high saving rates. Simulations incorporating these stylized facts suggest that their share of wealth is not likely to decline in response to fiscal interventions alone. Creation of an independent public wealth fund could lead to greater equality. Similarly, once-off tax/transfer packages or wage increases will not reduce income inequality significantly; on-going wage increases in excess of productivity growth would be needed.

It is possible to reduce US wealth and income disparity, but reversing unequalizing trends for the past 30 or 40 years will not be easy or quick.

\section{Cambridge controversies}

Issues of distribution came up long ago in the small recondite world of the theory of capital. They were front and center in the 1960s in a fierce debate between economists at the University of Cambridge in the UK and opponents at MIT in the USA. The subtext, for Cambridge UK at least, was that economic structure responds to power 
relationships and class. MIT on the other hand traced the cause of inequality to market forces. The British "won" the theory debate, but lost the profession. ${ }^{1}$

Current debate concentrates on how income and wealth are distributed across households classified by the size of their holdings. Macroeconomic growth and capital theories, on the other hand, focus on the nature or function of payments flows, assets, and liabilities. We can say something about how size distributions relate to functional distinctions, but the inferences can be tricky. Let's start with distribution as treated in macro theories, and later look at extensions toward size.

Current orthodoxy took shape 60 years ago in a powerful paper by Solow (1956). ${ }^{2}$ Piketty organizes his narrative around the Solow model which rests on very strong assumptions. The list includes (i) labor $(L)$ and capital $(K)$ can be measured unambiguously and are fully employed; ${ }^{3}$ (ii) output $(X$, e.g. "real" GDP) is determined from the supply side by an "aggregate production function" based on $L$ and $K$; (iii) both inputs are subject to decreasing returns to scale in production; (iv) growth of $K$ is determined by saving; and (v) growth of the labor supply and employment is set by exogenous population dynamics.

Finally, because of diminishing returns, the "marginal product" of an extra unit of capital decreases when the capital/labor ratio $K / L$ and capital/output $K / X$ go up. From an ancient recipe concocted by the American economic Darwinist John Bates Clark (1908) capital's marginal product is supposed to be equal to the profit rate (say $r$ ). In other words, a high level of the capital/output ratio implies that $r$ will be low, the real wage (say $\omega$ ) will be high, and presumably the income distribution will be egalitarian. 
Capital theorists (not to mention engineers or architects designing factories or housing) have always focused on how producers minimize costs of production including profits by utilizing labor and capital. The Cambridge UK vs USA debate centered on least cost "techniques" for combining different sets of capital goods as the rate of profit changes. The production cost of each good depends on $r$ along with the prices of the other goods so the interactions are complicated. After the dust had settled, all participants agreed that the same technique could be cheapest to deploy at two or more different levels of $r$, with other techniques being optimal in between. Consequently, there is no clear relationship between the total value of $K$ and $r$. Clark and Solow's (as well as Piketty's) key assumption about how $r$ and $\omega$ respond to the "size" of the capital stock does not apply.

Less esoterically, Solow's narrative does not fit the past three or four decades of US data. The usual scenario is that that capital/labor ratio starts from a low level and rises. Along Clark's lines, $r$ falls and $\omega$ goes up. Producers respond to the lower profit rate by using more capital so that the output/capital ratio $u=X / K$ goes down. ${ }^{4}$

Figure 1, based on national accounts data including corporate profits, shows that across US business cycles (recessions are shaded) $u$ and $r$ have drifted upward since around 1980. The real wage at best has been stable. This history is consistent with the Solow model running in reverse. The economy has "too much" capital per worker. The $K / X$ and $K / L$ ratios gradually run down as the system converges toward a "natural" growth rate set by expansion of the fully employed labor force. Given the state of infrastructure and perisistent underemployment in the USA, this interpretation looks absurd. With help from Karl Marx, a more plausible interpretation of recent trends is presented below. 


\section{Figure 1}

The share of profits $(\pi)$ in output is given by the formula $\pi=r / u$. The diagram shows that it varies pro-cyclically, and also increased on trend after 1980. In the Solow model, $\pi$ can go up if $r$ rises more than in proportion to $u$, as occurs when a parameter called the elasticity of substitution of the production function lies between zero and one. ${ }^{5}$ Standard econometrics supports a low value of the elasticity, but Piketty wants it to exceed unity. You can't have it both ways.

\section{Distribution of wealth}

Piketty and Piketty and Zucman (2014) deal with the wealth of households, with emphasis on the effects of rising asset prices. As noted above, for any group of economic actors their accumulation is given by

Change in wealth $=$ Net saving + Capital gains .

Net saving is total saving (income - consumption - taxes) minus depreciation. Capital gains are increases in the prices of assets that the group holds. Piketty and Zucman argue that close to $30 \%$ of the increase in household net worth over recent decades has been due to increases in prices of equity and housing (especially the latter).

To shed light on this conclusion we have to go back to capital theory, which has always been about costs. The standard procedure for estimating the capital stock, called the "perpetual inventory" method, does not take Cambridge complications into account, but at least it does examine the costs of producing new capital goods and how rapidly they depreciate in use. In standard accounting, capital estimated in this fashion fits into the equation for total net worth of the private sector, 


$$
\begin{aligned}
& \text { Household wealth + business wealth } \\
& =\text { Private Capital + Government debt + Net foreign assets }
\end{aligned}
$$

with private capital as by far the biggest entry in the supply of wealth on the right-hand side. ${ }^{6}$

Under perpetual inventory accounting, private capital is constant at any point in time. For a given right-hand side, if household wealth goes up, then business wealth must go down. On the other hand, if the value of capital rises (for given levels of debt and net foreign assets), then private sector wealth must increase as well. Whether households or corporations benefit is not immediately clear. Piketty credits households with the gain.

To follow the distributional details we have to drop the assumption in growth models that "households" populated by human beings directly own all the capital stock. In fact, their wealth or net worth comprises a big collection of disparate assets less liabilities. Figure 2 provides a highly simplified schema in the form of "T-accounts" or balance sheets for households, (corporate) business, the government, and the financial sector (the rest of the world is ignored). For each sector, the value of assets is on the left, liabilities and net worth on the right.

\section{Figure 2}

Households hold physical capital (residences, basically), equity issued by business and finance, bonds from business and government, and money. They also hold diverse financial products such as mutual funds, insurance, pension plans, and 
options labeled here as "funds." They owe debt (mostly mortgages) to finance, and have positive wealth or net worth.

Business firms hold productive capital (plant and equipment along with inventories). In macro accounts, their outstanding equity is reckoned as a liability along with bonds. As will be seen, business net worth in the USA is typically negative in recent decades because the value of their outstanding equity exceeds the value of their capital stock when it is estimated by perpetual inventory.

Government holds capital (infrastructure) and issues bonds. Its net worth is negative. As noted in (2) above, the bonds contribute to net worth of the private sector (mostly households).

The private financial sector holds debt and "base money" issued by the central bank (nowadays greatly exceeding money held by households due to quantitative easing following the financial crisis). Traditionally, banks within the sector offered deposits and made loans to business and households. But since the 1970s there has been an eruption of new instruments, some held by households (funds). But there are also major transactions within finance, for short here called "repo" (for repurchase agreement or a form of loan) and "reverse repo." In practice, assets and liabilities of the financial sector are nearly equal and both trended up from around $40 \%$ of total wealth in 1980 to over $120 \%$ today. $^{7}$

A path into Figure 1's financial thicket is offered by the national accounts, which state that

Total profits $\approx$ Financial transfers to households + Business saving. 
To a good approximation corporate earnings are distributed to households as interest and dividends or else retained within business. ${ }^{8}$ This saving including depreciation ("capital consumption allowances" or CCA in national accounts jargon) runs around $10 \%$ of GDP. Net of depreciation, business saving is in the range of one or two percent.

\section{Capital and capital gains}

How do households get their hands on profits embodied in business net saving? The answer is capital gains on equity, boosted in the recent period by share buybacks (often financed by higher business debt). ${ }^{9}$ Of the traditional seven percent "long run" return to US equity, over half is made up by asset price increases plus buybacks, and the rest by dividends.

Figure 3 presents data on all realized capital gains (including residential housing) since the mid-1980s. On the whole, yearly gains by households exceed net business saving. Sums exceeding profits are transferred to households via financial flows and asset price changes, running down firms' net worth.

\section{Figure 3}

What forces cause capital gains is a vexed and open issue. As discussed below, capitalization of rents may enter the process by driving up property valuations which get channeled to owner households. Similarly, capitalization of the rising profit share may have increased equity values. Low interest rates beginning in the mid-2000s no doubt contributed. The corporate governance philosophy of maximizing shareholder value also played a role (and one might add the strategy of executives paid in the form of 
stock options to run up business debt to retire their companies' shares to prop their option values up). Share buybacks were around a trillion dollars in 2015.

A snapshot of the US wealth distribution for 2012 appears in Figure 4, based on a capital stock series from the Bureau of Economic Analysis, the Federal Reserve's " $Z$ tables" of Financial Accounts, and Edward Wolff's (2012) breakdown of the size distribution of holdings which comprise physical capital, the value of equity, and other financial instruments ("bonds"). Assets held by each group of actors have a negative sign; liabilities and net worth are positive. The numbers don't add up --reported holdings of bonds by households and finance exceed the supply from firms, government, and the rest of the world.

\section{Figure 4}

Based on perpetual inventory estimates, the capital stock breakdown in the first column is a skeleton key to interpreting the balance sheets. Consistent with the data on flows in Figure 3, the numbers show that the business sector has negative wealth. The value of equity outstanding ( $\$ 29,483$ trillion) substantially exceeds firms' capital stock (\$19,903 trillion). Debt of almost two trillion pushes business further into the red. The sector's negative net worth of $-\$ 11,354$ trillion offsets $16 \%$ of household wealth, or half the contribution Piketty and Zucman attribute to capital gains.

Piketty and colleagues sidestep this problem by using stock market valuations directly to estimate the amount of the capital stock. ${ }^{10}$ To see if this procedure makes sense, requires a detour into corporate finance theory. In a subtle argument, Fischer Black and Myron Scholes (1973) point out that a share is really an option on the value 
of a firm if it closes down at some future time. Its physical capital can be sold, presumably in line with its original cost less depreciation, and bondholders must be paid off. Equity owners "share" the remainder which may well be less than the value of stock outstanding.

To offset the differential between value of equity and capital at replacement cost (minus debt), large amounts of "intangible capital" must be conjured into existence if $K$ is to be valued using share prices. In terms of Figure 4, if the absolute levels of capital are raised to approach the value of equity, then net worth of both households and (especially) firms can go up. Ratios of personal wealth to income can skyrocket

Another viewpoint on the situation comes from James Tobin's (1969) "valuation ratio" or $q-$ a firm's equity valuation divided by the replacement value of its capital stock (or perhaps capital minus debt). ${ }^{11}$ If as in Figure 3, household capital gains exceed net business saving, then $q$ must rise. Estimates differ in detail, but after around 1980 in the USA $q$ went up from about 0.4 to a level well over $1.0 .{ }^{12}$

This configuration of wealth-holding is not inevitable. Coming out of World War II and into the 1960s American corporations had positive net worth with capital estimated by perpetual inventory. Till van Treeck (2015) points out that even today German business has positive net worth stemming from profits created by the economy's consistent trade surplus, and explores the implications. Unsurprisingly in light of Figure 2's accounting, positive wealth in German business goes along with a low ratio of the value of equity to the capital stock or $q<1$, a fact that surprises Piketty and Zucman.

For future reference we can take a quick look at ownership of capital in the table. Households in the table are split into the top $1 \%$ and the bottom $99 \%$ of holders of 
wealth (the $20 \%-80 \%$ split is also included for reference). The top $1 \%$ directly own $35.4 \%$ of household net worth, consistent with other estimates. They hold only $26.9 \%$ of household capital stock, basically residential housing (the top $20 \%$ hold $80.7 \%$ !). Households overall hold roughly one-third of capital, and business holds around onehalf. The rest belongs to government.

We take up implications of this pattern of wealth-holdings below. But one final thought is that a continuing transfer exceeding net saving from business to households is unlikely to endure forever. Equity is a claim on firms' profit flows. In a "perfect" capital market, the value of the firm $q$ (relative to capital) should be its profit flow $r$ "capitalized" at a real interest rate $i$ coming from the market: $q=r / i$. In the USA, interest and profit rates tend to be negatively correlated and bear no clear relationship to $q$. The value of $q$ rose steadily in the two decades after 1980 but a continuing increase will not be observed. Nor is a very high level likely to persist.

\section{The role of rent}

Piketty and Joseph Stiglitz (2014) point to "capitalized rents" as a significant source of wealth inequality. Tracing back beyond Adam Smith, rent can be viewed as payment for the use of some asset. In other words it is a monopoly price, supported by ownership claims and a threat of coercion (legally sanctioned or otherwise).

The conditions that give rise to rent are often left unstated. One is that simple scarcity of some input into production (say agricultural land or oil in the ground) can give rise to non-zero payments from users to owners of the scarce resource.

Second, "rent-seeking" (Anne Krueger, 1974) is a favored vehicle for mainstream economists to bring class and power into discussion. Rents become claims on income 
associated with sociopolitical relationships which do not themselves create income. For example a firm bribes politicians to get legislation increasing its profits. ${ }^{13}$ This version was popularized by Gordon Tullock (1967). Even he, however, emphasized difficulties in identifying rent-creating claims.

Finally, market power per se can move prices away from the values that would be observed in a "competitive" situation - this form of rent is the standard neoclassical version of exploitation. "Imperfect information" about how different classes of economic actors operate is a recent justification for the existence of market power. A monopoly position is an artifact of the social and institutional structures in place at the time. Over the past few decades they have shifted in favor of capital, with visible consequences.

Rents, legitimate or not, become sources of wealth inequality if they are capitalized. Suppose that some rental flow $\rho$ is associated with the stock of an asset just how $\rho$ gets determined is usually left unexplained. The value $V$ of the asset in question (land, politically sanctioned diversions of income, whatever) should be given by $V=\rho / i$. Of course, for a given $\rho, V$ gets bigger when the interest rate goes down. Total wealth $\Omega$ is now given by $\Omega=K+V$ which seemingly can be arbitrarily large. Of course any widespread attempt to sell assets would immediately drive down prices and destroy wealth. We learned all about that during the financial crisis.

The crucial question is how rents can be measured. They are payment flows within the macro system - money changes hands. For better or worse, Piketty pulled Jane Austen into the discussion so let's use Pemberley as an illustration of scarcity rent. Mr (and eventually Mrs) Darcy's income of $£ 10,000$ came from rents on 10,000 acres (or 16 square miles) of cropland around Pemberley House. Rents were based on sales 
of grain at a relatively high price before repeal of the Corn Laws and later massive imports from the USA and Ukraine. The Darcys flourished financially from a big payment flow in the political economy of their time. Large landowners as a class did well because agriculture made up half of economic activity as opposed to a few percent at present.

What is the role of rents today? Because they are transactions within the system, in principle they should show up in the national accounts. The problem is that rents are not large. In the US numbers agriculture is tiny and rents on housing are a few percent of GDP (although they have trended upward since 2000). The political economy is that rather than being driven by a robust agricultural sector as with the Darcys, high land rent currently is a consequence of asset accumulation supported by other sources of income, e.g Manhattan's new "billionaires' row" on $57^{\text {th }}$ street supposedly is financed by foreign and Wall Street fortunes. Shifting assets from other sources into 1000-foot towers (once they are built) does not constitute creation of new wealth. A similar observation applies to "resource rents" in a few raw material exporting countries. They reflect the transformation of resources in the earth into financial flows.

In the USA, if you capitalize a rental flow of five percent of GDP at five percent, you find a level of wealth equal to one year's GDP. In Figure 4, that is roughly the value of US residential housing, estimated using perpetual inventory. Stiglitz presents a numerical example in which rents are $30 \%$ of output of other goods plus rental income. What country does he have in mind? With oil rents, Iran and Kazakhstan come close.

Stiglitz and Solow (2015) attribute rising corporate profits to monopsony power in the labor market. Figure 1 suggests that the profit share has increased by around five 
percentage points over the last 40 years. Backing away from his 1956 growth model assumptions about full employment and perfect competition, Solow sensibly explains the offsetting decrease in the labor share on institutional grounds including " the decay of unions and collective bargaining, the explicit hardening of business attitudes, the popularity of right-to-work laws, and the fact that the wage lag seems to have begun at about the same time as the Reagan presidency all point in the same direction: the share of wages in national value added may have fallen because the social bargaining power of labor has diminished."

Mainstream economists argue that business now can appropriate more "rents" within the structure of costs than it could some decades ago. Radicals could decry exploitation. Either way, if the increase in the profit share is capitalized, it too represents a year's worth of GDP, or roughly half the value of outstanding equity. Piketty's calculation of the value of capital and the rise in Tobin's $q$ are consistent with capitalization of extra profits caused by lagging wages. Over time, regressive income redistribution in the medium run appears to have extended to maldistribution of wealth.

\section{Back to Cambridge}

There are two further strands of theory from Cambridge University that illustrate distribution today. One is about determination of output and the profit share in the short to medium run. The other sheds light on the long-run distribution of wealth. Both emerge from a non-Say's Law demand-driven analysis of growth.

The assumptions underlying the models are the following: (i) labor and capital can be measured unambiguously but they are not fully employed; (ii) output is determined by effective demand, which brings saving into line with the sum of 
investment, the fiscal deficit, and the trade surplus; (iii) employment is set by output divided by labor productivity; (iv) capital does not directly affect output but does set the scale of the system; (v) growth of capital is determined by investment; (vi) the classbased functional income distribution is set by conflict or competition between workers and business; and (vii) saving and investment depend on the income distribution.

Marx throws light on distribution, in contrast to the Solow model's explanation of recent trends discussed above. In several passages in Capital, he sketched a theory of business cycles (a century later formalized by the American-born Cambridge economist Richard Goodwin, 1967) pivoting on shifts in the income distribution. At the bottom of a cycle, the real wage is held down by a large reserve army of un- or under-employed workers, and capitalists can accumulate freely. However, as output expands the reserve army is depleted as capital utilization $u$ goes up. The real wage rises in response to a tighter labor market, forcing a profit squeeze. The "Conflict" schedule in Figure 5 illustrates this linkage from $u$ to $\pi$.

\section{Figure 5}

The other side of Marx-Goodwin macroeconomic adjustment is a positive effect of $\pi$ on $u$, operating though investment demand or exports, illustrated by the "Demand" curve in Figure 5. Initially, medium-run macro equilibrium is at point $\mathrm{F}$, with $\pi$ and $u$ following clockwise cycles around it. ${ }^{14}$

The diagram provides a plausible explanation for the trends mentioned above rising $u$ and $\pi$, falling or stable $\omega$. Simply put, in the USA the $\pi(u)$ schedule drifted upward for the past 30 or 40 years - the profit squeeze mechanism still exists but has 
become weaker. One can see this pattern in the data. The labor share $\psi=1-\pi$, and in turn $\psi=\omega / \xi$ where $\xi=X / L$ is labor productivity. Because of shifts in labor market institutions $\omega$ has been stable while $\xi$ has increased over time, shifting the functional income distribution toward profits and stimulating demand. The impact has been to move the focal point of the economy from point $F$ to $G$.

If we maintain the growth theory convention that all capital is owned by households, medium run macroeconomics extends to a "long run" steady state as formulated in Cambridge's Luigi Pasinetti $(1962,1974)$. The emphasis is on how saving supported by existing asset holdings feeds into their growth. Intangible capital and evanescent rents do not figure in the discussion.

Pasinetti assumes that there are two distinct classes - "capitalists" and "workers." Their respective saving rates are $s_{c}$ and $s_{w}$ with $s_{c}>s_{w}$. Capitalists receive profits $r K_{c}$ from the capital $K_{c}$ that they own, while workers get the rest of income.

Steady state growth means that all relevant variables increase at the same exponential rate $g$. For all variables the ratios of their increases to their levels must be the same. Two useful formulas follow.

One is Pasinetti's elegant relationship

$$
s_{c} r=g
$$

which shows that the capitalists' saving rate mediates the magnitudes of the growth and profit rates. With $s_{c}<1$ we already have $r>g$, an inequality which Piketty emphasizes. The basic intuition is that at a steady state, the saving/wealth ratios of both capitalists and workers must equal the ratio economy-wide. Equation (4) for capitalists follows directly, a conclusion that Piketty does not recognize. ${ }^{15}$ 
Second, let $Z=K_{c} / K$ be the capitalists' share of total capital. For worker households, the steady state flow/stock condition just mentioned implies that their share of wealth is

$$
1-Z=\left[s_{w} /\left(s_{c}-s_{w}\right)\right][(1-\pi) / \pi] .
$$

Wealth shares in the long run are intimately related to the distribution of income between profits and wages, and thereby social change and redistributive policy. The workers' share, $1-Z$, increases with $s_{w}$ and decreases with $s_{c}$ and $\pi$. The former effect reflects James Meade's (1964) observation that wages are a potential source of saving unavailable to rentiers, setting an upper limit to $Z$. A corollary is that because of their different sources of income both classes will co-exist in steady state.

Pasinetti's world is abstract. Balance sheets as in Figure 2 are ignored, along with the large increase in household debt prior to the Great Recession. In practice there are no "pure" capitalists and workers. Nevertheless households in the top one percent in the USA are not a bad approximation to a capitalist class. Following Lance Taylor, Ozlem Omer, and Armon Rezai (2015), Figure 6 summarizes their mean income levels per household over time - late in the decade it was more than $\$ 2$ million per year. The segments toward the bottom of the bars show that the well-off did receive growing pretax income from labor compensation, around seven percent of the total economy-wide. But bigger chunks come from interest and dividends along with rents and proprietors' incomes. Capital gains were substantial in many years. We can treat the upper one percent as approximating abstract Pasinetti capitalists.

\section{Figure 6}




\section{Sources of Inequality}

Meade's argument (above) shows that $Z$ will not rise to a value of one.

Capitalists' wealth cannot expand indefinitely, as Piketty seems to imply. Even so, the upper bound may be high. A plausible saving rate for the top one percent of households is in the vicinity of $s_{c}=0.5$. The rate for the rest could be $s_{w}=0.1$. From Figure 1 , the corporate profit share of GDP is in the range of 0.25 . In the household accounts the combined GDP share of proprietors' incomes, rent, and depreciation is about 0.12 , so the overall return to capital might be around 0.33 . These numbers generate a steady state value for $Z$ of 0.5 , above the level of 0.4 for the top one percent of wealth-holders that most authors calculate today.

Simulations of possible growth paths in a numerical version of the models just sketched suggest that it would be very difficult to reduce income and wealth inequality significantly just by using policy measures such as taxes on upper incomes, capital gains, or net worth. These conclusions are built into national income and financial accounting numbers with proper attention to dynamics. William Gale, Melissa Kearney, and Peter Orzag (2015) got such results regarding income a year or so after Taylor, et.al. (2015) and earlier papers.

With regard to wealth, Andrew Mellon, Secretary of the Treasury under the string of Republican presidents in the 1920s, said that "During a Depression, assets return to their rightful owners." In fact, he was wrong. Under almost all circumstances, assets move toward "rightful" households who already hold a preponderant share. To get that share back below the current $40 \%$ and keep it there, the market needs an actor with countervailing power against the accumulation of the very rich. Creation of an institution 
such as a public wealth fund to out-save the savers would be required to mitigate their control of national net worth.

In the short run income inequality can be reduced by one-shot measures such as boosting low wages or raising taxes at the top. But even if applied aggressively these moves will not erase income differentials between the rich and the poor or middle class unless new resources can be directed toward lower income households. Higher labor productivity (output per person-hour) can provide such a flow of resources. After 1980 US productivity gains favored the top one percent because wage growth did not keep up. Economic surplus moved from almost all other households toward the very rich. Reversing the flow would take substantial intervention into labor relations.

\section{Notes}

1. When they surface today, results of the controversy are often misstated. For example, the economics commentator John Kay wrote in the Financial Times (October $6,2015)$ that "Robert Solow [from MIT] won easily because of the care he took to specify ... his models" and that the other side was led by the "Cambridge Marxist economist Joan Robinson." In fact Solow's colleague Paul Samuelson (1966) graciously conceded that MIT was wrong. Even so, macroeconomic courses at leading US departments continued to be based on the theory that failed. MIT's canonical textbook by Olivier Blanchard and Stanley Fischer (1989) did not bother to mention the controversy. Joan Robinson was a left Keynesian, not a Marxist, and a full professor at Cambridge. The classic reference is G. C. Harcourt (1972).

2. The Australian economist Trevor Swan (1956) independently invented the same model.

3. In his General Theory, Cambridge's preeminent economist John Maynard Keynes (1936) dismissively labeled this assertion Say's Law after an early $19^{\text {th }}$ century French scholar. The Law implies that any excess of income over consumption and taxes somehow gets automatically translated into an increase in the capital stock. For example, savings newly deposited in a bank immediately get lent to a firm to purchase new equipment or to a contractor to build a house.

4. The calculation of $u$ relies on the rough-and-ready "perpetual inventory" estimate of $K$ used in the US national income and financial accounts (details below). The profit share $\pi$ is calculated using "net operating surplus" estimates from the US 
national accounts (Table 1.16). The profit rate follows from the accounting equation $r=$ $\pi u$.

5. In any case, the elasticity is a messy mélange of productivity, distributive, demographic, and demand shifts (Nelson Barbosa-Filho, forthcoming) - not a useful parameter.

6. Equation (2) follows from consolidating the "Balances" in a version of Figure 2 (just below) extended to include liabilities of the rest of the world such as reserves of the central bank and national liabilities that it holds.

7. Perry Mehrling's (2010) New Lombard Street is a useful summary of the current state of finance.

8. The " $\approx$ " signals that equality is only approximate (to roughly three significant digits) because of minor transfers not intermediated via claims in the financial system.

9. William Lazonick (2015) gives an insightful review.

10. He is not cited by Piketty, but some time ago Robert Hall (1981) of Stanford's Hoover Institution came up with similar results in a high tech paper.

11. The basic idea can be traced to Thorstein Veblen, Gunnar Myrdal, Robin Marris (who called the ratio $v$ in his theory of the firm) and Keynes.

12. Estimating $q$ is tricky. José Gabriel Palma (2009) reports an increase from around 0.5 to 2.5 between 1980 and 2000 .

13. Which relationships generate income is another tricky question. Import quotas are legally sanctioned public-private relationships often used to exemplify targets of rent-seeking. But restrictions on imports helped stimulate industrialization in Korea, so were they unproductive?

14. For details see Nelson Barbosa-Filho and Lance Taylor (2006), who work with the wage as opposed to the profit share. Cycles in $\pi$ and $u$ are evident in Figure 1.

15. That is, capitalists' ratio of saving to wealth is $s_{c} r$ and the economy-wide ratio is $g$.

\section{References}

Barbosa-Filho, Nelson H. (forthcoming) "Elasticity of Substitution and Social Conflict: A Structuralist Note on Piketty's Capital in the Twenty-First Century," Cambridge Journal of Economics. 
Barbosa-Filho, Nelson H., and Lance Taylor (2006) "Distributive and Demand Cycles in the U.S. Economy - A Structuralist Goodwin Model, Metroeconomica, 57: 389411.

Black, Fischer, and Myron Scholes (1973) "The Pricing of Options and Corporate Liabilities," Journal of Political Economy, 81: 637-654

Blanchard, Olivier Jean, and Stanley Fischer (1989) Lectures on Macroeconomics, Cambridge MA: MIT Press.

Clark, John Bates (1908, 2008 reprint) The Distribution of Wealth: A Theory of Wages, Interest, and Profits, Gloucester UK; Dodo Press.

Gale, William G., Melissa S. Kearney, and Peter R. Orzag (2015) "Would a Significant Increase in the Top Income Tax Rate Substantially Alter Income Inequality?" http://www.brookings.edu/ /media/research/files/papers/2015/09/28-taxes-inequality/wouldtop-income-tax-alter-income-inequality.pdf

Goodwin, Richard M. (1967) "A Growth Cycle," in C. H. Feinstein (ed.) Socialism, Capitalism, and Growth, Cambridge UK: Cambridge University Press.

Hall, Robert E. (1981) "The Stock Market and Capital Accumulation," American Economic Review, 71: 1185-1202.

Harcourt, G. C. (1972) Some Cambridge Controversies in the Theory of Capital, Cambridge UK: Cambridge University Press.

Keynes, John Maynard (1936) The General Theory of Employment, Interest, and Money, London: Macmillan.

Krueger, Anne O. (1974) "The Political Economy of the Rent-Seeking Society," American Economic Review, 64: 291-303. 
Lazonick, William (2015) "Stock buybacks: From retain-and-reinvest to downsize-anddistribute," Center for Effective Public Management at Brookings, http://www.brookings.edu/ /media/research/files/papers/2015/04/17-stockbuybacks-lazonick/lazonick.pdf

Meade, James E. (1964) Efficiency, Equality, and the Ownership of Property, London: George Allen \& Unwin.

Mehrling, Perry (2010) The New Lombard Street: How the Fed Became the Dealer of Last Resort, Princeton NJ: Princeton University Press.

Palma, José Gabriel (2009) "The Revenge of the Market on the Rentiers: Why NeoLiberal Reports of the End of History Turned Out to be Premature," Cambridge Journal of Economics, 33: 829-869

Pasinetti, Luigi L. (1962) "Income Distribution and Rate of Profit in Relation to the Rate of Economic Growth, Review of Economic Studies, 29: 267-279.

Pasinetti, Luigi L. (1974) "The rate of profit in an expanding economy," in Growth and Income Distribution: Essays in Economic Theory, Cambridge: Cambridge University Press.

Piketty, Thomas (2014) Capital in the Twenty-First Century, Cambridge MA: Belknap Press.

Piketty, Thomas, and Gabriel Zucman (2014), "Capital is Back: Wealth-Income Ratios in Rich Countries, 1700-2010," Quarterly Journal of Economics, 129: 1255-1310.

Samuelson, Paul A. (1966) "A Summing up," Quarterly Journal of Economics, 80: 568583. 
Solow, Robert M. (1956) "A Contribution to the Theory of Economic Growth," Quarterly Journal of Economics, 70:65-94.

Solow, Robert M. (2015) "The Future of Work: Why Wages Aren't Keeping Up," Pacific Standard, August 15, https://psmag.com/the-future-of-work-why-wages-aren-tkeeping-up-6fcfac468e4\#.j0iys3wc8

Stiglitz, Joseph E. (2014) "New Theoretical Perspectives on the Distribution of Income and Wealth among Individuals," New York NY: Initiative for Policy Dialog at Columbia University.

Swan, Trevor W. (1956) "Economic Growth and Capital Accumulation," Economic Record, 32: 334-36.

Taylor, Lance, Ozlem Omer, and Armon Rezai (2015) "Wealth Concentration, Income Distribution, and Alternatives for the USA," http://ineteconomics.org/ideaspapers/research-papers/wealth-concentration-income-distribution-andalternatives-for-the-usa

Tobin, James (1969) "A General Equilibrium Approach to Monetary Theory," Journal of Money, Credit, and Banking, 1: 15-29

Treeck, Till van (2015) " $r>g$ : Why the 'Piketty Debate' Unsettles Germany's Economic Experts," Munich: CESifo Forum, 16 (no. 1): 26-34.

Tullock, Gordon (1967) "The Welfare Costs of Tariffs, Monopoly, and Theft," Western Economic Journal, 5: 224-232.

Wolff, Edward N. (2012) "The Asset Price Meltdown and the Wealth of the Middle Class," NBER Working Paper 18559. 
Figure 1: US output/capital ratio, profit share, and profit rate

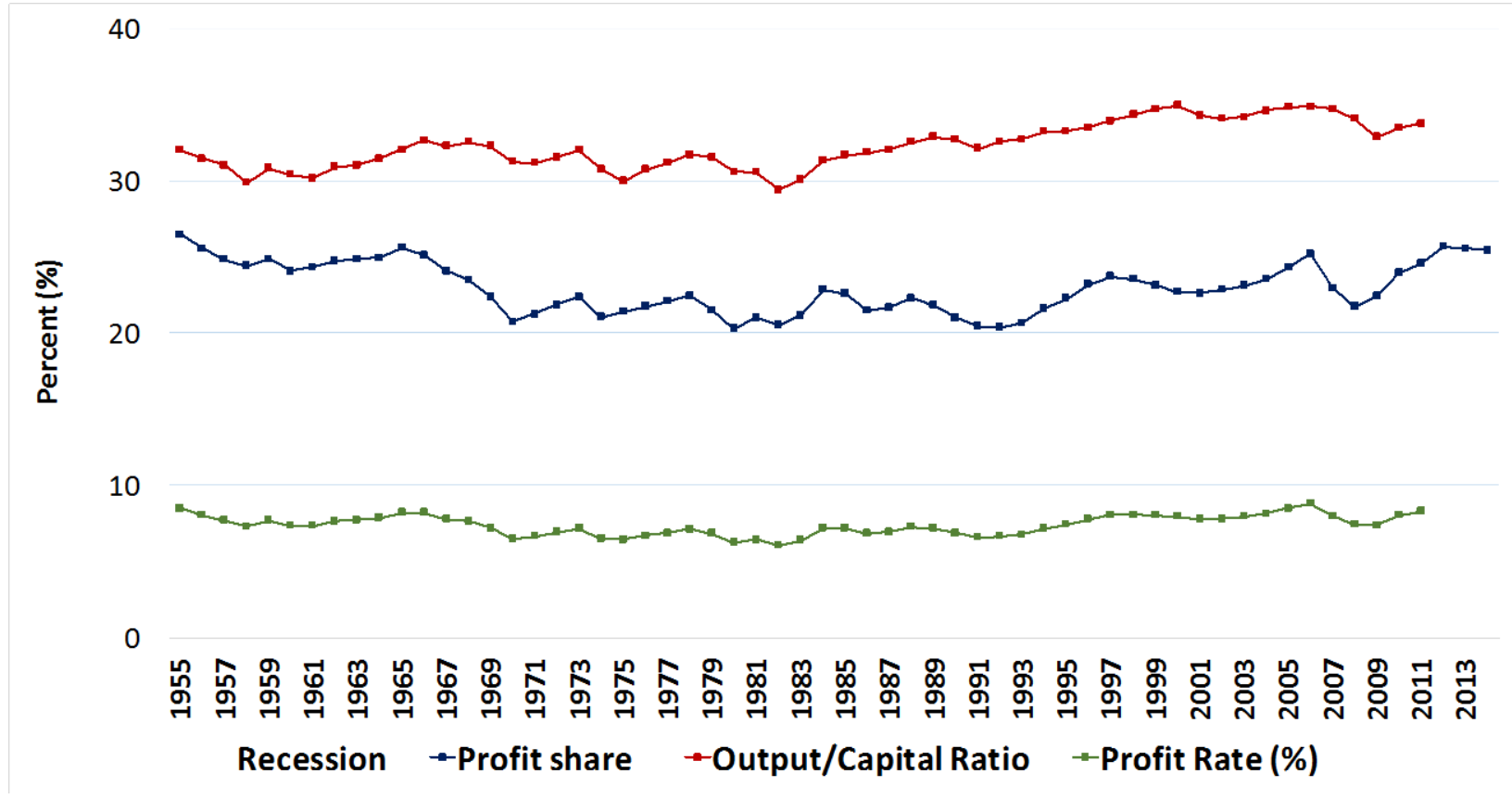


Figure 2: Stylized balance sheets for the US economy

Households

Capital(h) Debt(h)

Equity

Bonds

Money

Funds
Business

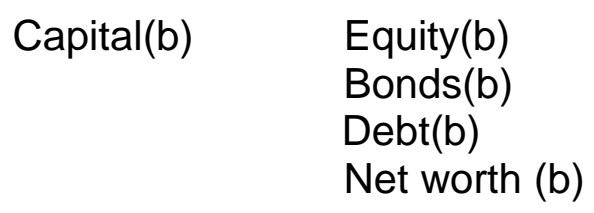

Capital(b)

Equity(b)

Bonds $(b)$

Debt(b)

Net worth (b)

Government

Capital(g) Bonds(g)

Central Bank

Base money

Balances: Bonds $=$ Bonds $(\mathrm{b})+$ Bonds $(\mathrm{g})$

Capital = Capital(h) + Capital(b) + Capital (g)

Equity = Equity $(b)+$ Equity $(f)$

Debt $=\operatorname{Debt}(\mathrm{h})+\operatorname{Debt}(\mathrm{b})$
Finance

$\begin{array}{ll}\text { Reverse repo } & \text { Repo } \\ \text { Debt } & \text { Money } \\ \text { Base money } & \text { Funds } \\ & \text { Equity(f) }\end{array}$


Figure 3: Net business saving, business depreciation, and household capital gains

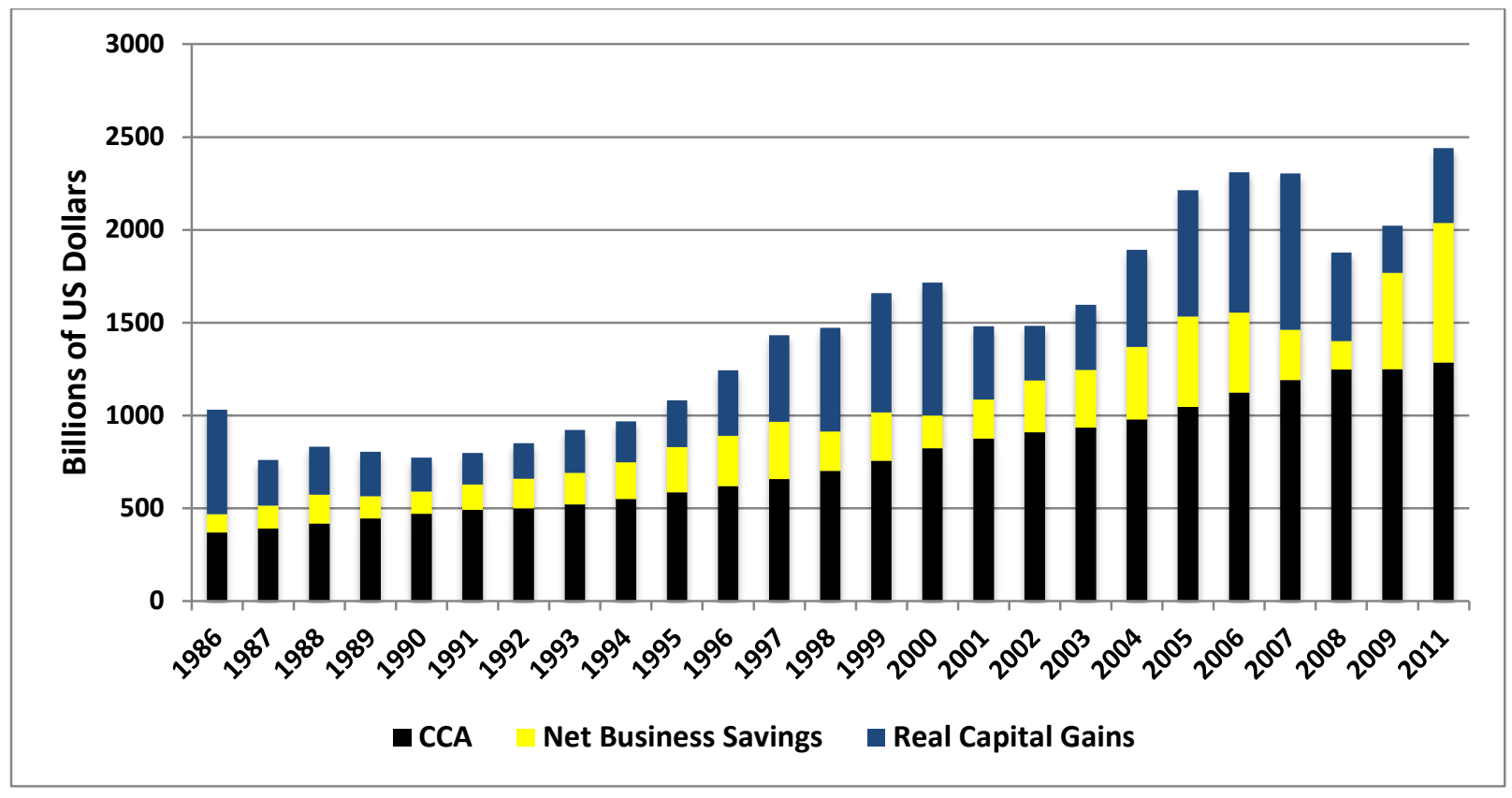


Figure 4: US assets (-) vs. liabilities (+) divided into capital stock, bonds and equity, and net worth by sector and household income groups, 2012. Levels in US\$ billions

\begin{tabular}{l|cccc} 
& Capital & Bonds & Equity & Net worth \\
\hline All HH & -16312.3 & -23769.1 & -28960.5 & 69041.9 \\
\hline Lower 80\% & -3154.7 & -3176.8 & -1332.2 & 7663.7 \\
Upper 20\% & -13157.6 & -20592.3 & -27628.3 & 61378.2 \\
\hline Lower 99\% & -11923.1 & -15909.8 & -16768.1 & 44601.1 \\
Upper 1\% & -4389.2 & -7859.3 & -12192.4 & 24440.8 \\
\hline Firms & -19903.3 & 1774.7 & 29482.6 & -11354.0 \\
Gov't & -12508.0 & 16862.8 & -279.9 & -4074.9 \\
Finance & & -5131.6 & -1047.2 & 6178.8 \\
R.O.W. & & 3175.3 & 805.1 & -3980.4 \\
\hline Col. sum & -48723.6 & -7087.9 & 0.1 & 55811.4 \\
\end{tabular}

Sources: Assets, liabilities, net worth from Financial Accounts (Federal Reserve, 2014); capital stock from Survey of Current Business (October, 2013), household groupings computed based on Wolff (2012). 
Figure 5: Determination of the profit share $\pi$ and capital utilization $u$. The dashed line shows the effect of an upward drift in the profit share.

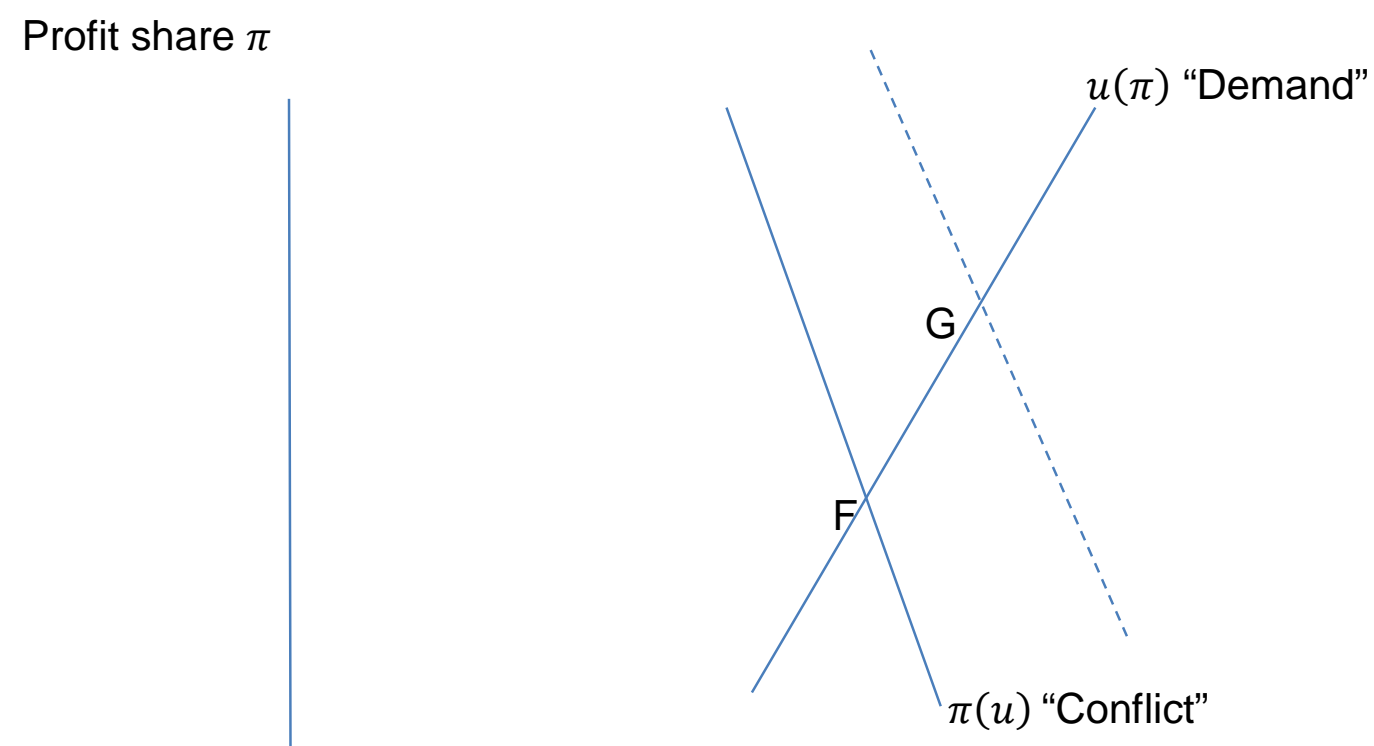

Capital utilization $u$ 
Figure 6. Real per household incomes top 1\%

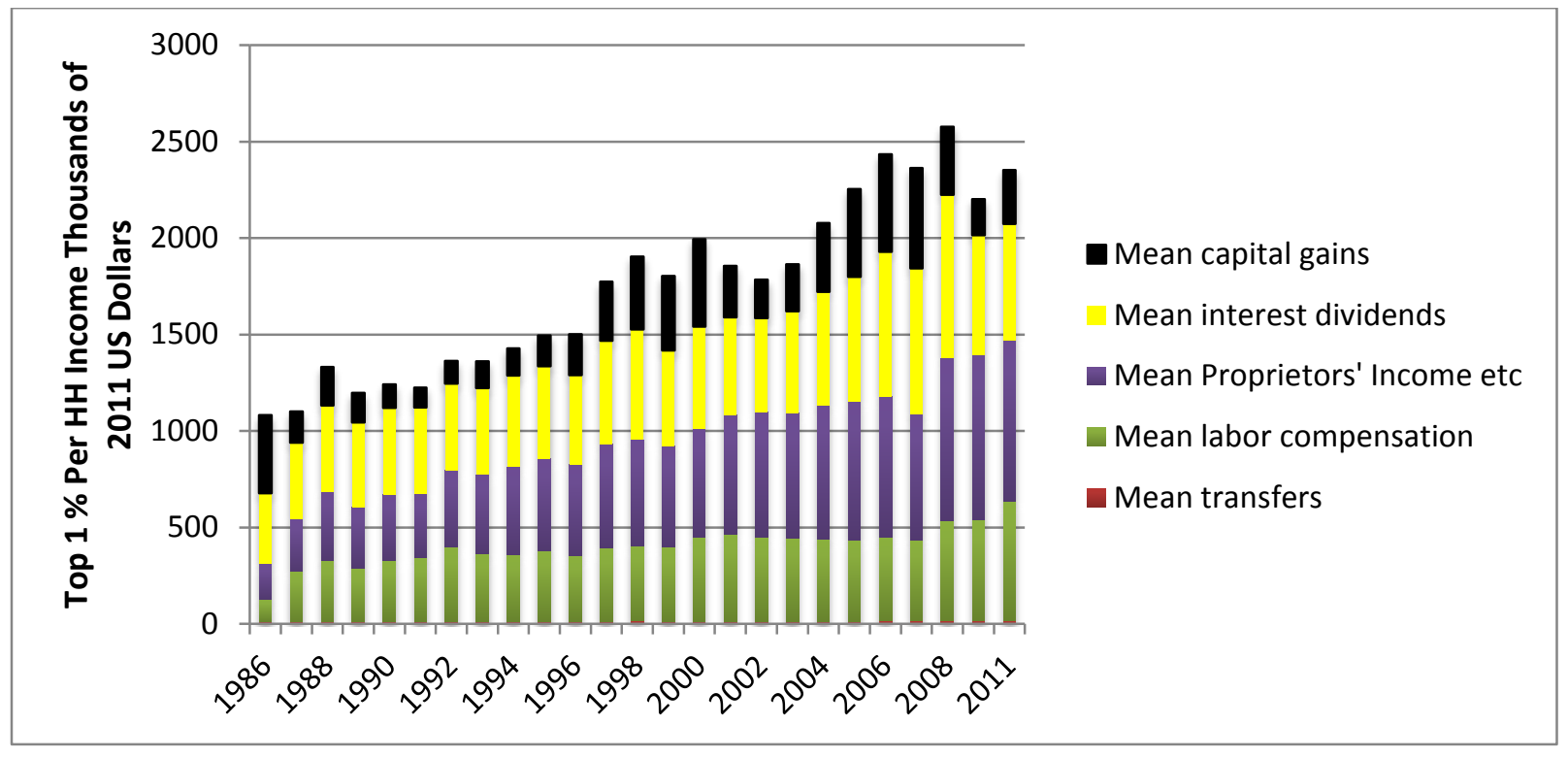

